\title{
Research on Nutrition Athlete of Petanque North Sumatera
}

\author{
Liliana Puspa Sari ${ }^{1}$, Ratna Dewi ${ }^{2}$ \\ Lecturer of Sport and Health Academy Bina Guna Medan
}

\begin{abstract}
Nutrition is one of the factors that influences the achievement of Petanque athletes of North Sumatra, so it is necessary to be considered and adjusted nutritional needs with physical activity during the training program. The aim of the study is to find about the nutritional status of Petanque athletes in The North of Sumatra in 2017. The research methodology is a descriptive method. The number of trial are fifteen people obtained through total sample techniques. The study was conducted at Petanque Dormitory High School of Sport and Health Bina Guna Medan. Instrument used to see the athlete's nutritional status is by using Body Mass Index (BMI) measurement which measured height, weight, and age of each athlete. In addition, also carried out questionnaires to the athletes who contained about the diet, diet, resting patterns and family background. The result of questionnaire is useful as input of this research. Furthermore, the measurement results are calculated using the formula BMI and then the calculation results are converted with BMI table to determine the nutritional status of athletes, whether in the state of lack, normal or obesity. Based on the calculation results obtained that the nutritional status of athletes Petanque North Sumatra is in the normal category of $93 \%$ (14 people), while 7\% (1 person) is in the category of obesity.
\end{abstract}

Keywords: Nutritional Status, and Petanque Athletes of North Sumatra

\section{Introduction}

Simply food is all that is eaten and drunk everyday by an athlete. Food substances are the basic ingredients that make up food ingredients. Food substances or nutrients are: carbohydrates, proteins, fats, vitamins and minerals. Foods that consume by the athlete should be well ordered to follow the flow needs of the athlete's activities. With other understandings, if the food is well ordered, of course, it will support the achievement of the athlete's achievement, and vice versa if athlete food is not organized will be a big problem in achieving. Arranging an athlete's diet certainly refers to the interests of the sports branch that the athlete occupies.

From the description above, the author found the initial question, whether the food consumed Petanque athletes of North Sumatra has to meet the calorie needs that are issued during exercise? To answer this question, there are several ways that can be done, among others, by monitoring the food menu consumed athletes then calculate the calorie content that contained in the food. In addition, it can also be calculated by measuring the nutritional status of the athlete.

After going through the planning and observation, the author gets information that research on the nutritional adequacy of Petanque athletes of North Sumatra has been studied by previous researchers. So the author is interested to examine the nutritional status of Petanque athletes of North Sumatra.

\section{Literature Review}

\section{Nutritional Nature}

The word comes from the Arabic word "ghiza" which means to eat, in this case the food can also be called nutrients. In general, the definition of nutrition is a processed food substance in the body which is then used by the body to growth and health of the body. Health is absolutely necessary for everyone to maintain the work function of the limbs to continue their activities and to maintain their survival.

According to A.Djaeni (1996: 20) "according to its function in the body, food substances that can also be divided into several parts, namely:

a) As a source of energy or energy

b) Supporting body growth

c) Maintain body tissue, replace damaged or worn out cells.

d) Regulates metabolism and regulates various balances.

e) Role in the body's defense metabolism against various diseases, such as anti-toxin and other anti-body.

It can be said that the role of nutrition is very important and is at the highest level in life. If the organ does not function properly then the organ can be said to have a health disorder in other words sick. If the organs are not functioning properly then the organs can not perform activities to the fullest. So good bad nutrition closely related to the health of the food consumed every day. Nutrition problem is not a problem that has been solved, not easy to achieve good nutrition. To achieve good nutrition one must understand and realize what it consumes. Eating less nutritious foods can be detrimental to health.

\section{The Role of Athlete Nutrition}

High achievement demands on the sportsman is very important, so that all fields of science have been applied for the achievement of the desired achievement. Including the application of nutrition is very important to be a concern. An athlete can go through the process toward desirable achievement should get the right energy from consuming foods containing the nutrients needed by the body during the exercise because good physical condition is supported by good nutrition as well.

In the fulfillment of nutritional needs is not an easy problem, because to achieve good nutrition there are conditions to be done and not just a full stomach. As described by Rahmat (1999: 1) "Good nutrition is food that provides the nutrients 


\section{International Journal of Science and Research (IJSR) \\ ISSN (Online): 2319-7064}

Index Copernicus Value (2016): 79.57 | Impact Factor (2015): 6.391

needed by the body in accordance with the activities undertaken".

According to Sunita Almatsier (2001: 132) "Humans need energy to sustain life, support growth and perform physical activity." Therefore an athlete should consume food or nutrients simply because in doing physical activity requires energy obtained from the burning of food Or nutrients. The nutrients obtained from the food we consume are explained by Suryadi (2006: 5) that "nutrients include carbohydrates (carbohydrates), fats, proteins, minerals, vitamins, and water.

\section{The Role of Nutrition in Exercise and Match}

For athletes who are in a special training period or regional training camp to prepare before or during the game need to get special attention in terms of nutritional needs level. According to Clark (2001: 94) "four functions of food before practice and match:

a) To help prevent hypoglycemia (low sugar levels), with symptoms of headaches, improper tiredness, blurred vision and can not concentrate.

b) Helps your stomach to be good, absorb sap belly, and eliminate hunger.

c) Filling muscle fuel, with food eaten far enough upfront to be digested and stored as glycogen.

d) To calm the mind with the knowledge that your body is fueled properly.

It should be noted by athletes who are undergoing training to keep the balance of fluid coming out of perspiration while practicing. The exhausted liquid should be replaced by drinking water as suggested by Djoko (2007: 107) "every 10-15 minutes drink 200-300 $\mathrm{ml}$ (1-2 cups), in hot weather the fluid requirement is increased 3 times from the recommended" . So for athletes at the time of exercise should drink water to restore the fluid that comes out, drinking water can also restore the freshness of the body.

Nourishment during the game according to Kasturi (2002:

20) "there are four main periods during the game period:

a) Initial season phase: needs depend on sex body size, intensity and duration of exercise.

b) Weight training phase: practice keeping double intensity.

c) Peak phase: 2-3 weeks before the competition. This is a very difficult phase, calorie intake should be adjusted based on the exercise produced.

d) Competition phase

- Pre competition: Last meal should be 4-5 hours before the game to keep blood sugar.

- During the glucose plymer competition can be used as a source of energy, during the regular fluid brake.

- Post competition: start recovery as soon as possible.

In the sports nutrition manual (Depdiknas, 2000: 3-5), "food menu is guided by 4 healthy 5 perfect fit with the taste and pattern of food of the people of Indonesia is a menu consisting of:

1) Staple food as a source of carbon hydrate.

1. Side dishes as protein and fat.

2. Vegetables as a source of vitamins and minerals.

3. Fruits as a source of vitamins and fats.
4. Milk, egg yolks or other substitutes as an additional source of high value protein.

\section{Energy Sufficiency}

The energy is needed for basal metabolism (BMR). Basal metabolism is a state of body metabolism in a state of complete physical and mental rest, one way to calculate a person's energy needs by estimating the value of BMR obtained by using the formula.

Table 1: The value of BMR (Basal Metabolism Rate)

\begin{tabular}{|c|c|c|}
\hline \multirow{2}{*}{ Age } & \multicolumn{2}{|c|}{ BMR (cal/day) } \\
\cline { 2 - 3 } & Male & Female \\
\hline $3-10$ & $22,7 \mathrm{~B}+495$ & $22,5 \mathrm{~B}+499$ \\
\hline $10-18$ & $17,5 \mathrm{~B}+651$ & $12,5 \mathrm{~B}+746$ \\
\hline $18-30$ & $15,3 \mathrm{~B}+679$ & $14,7 \mathrm{~B}+496$ \\
\hline$>30$ & $11,6 \mathrm{~B}+879$ & $87 \mathrm{~B}+89$ \\
\hline
\end{tabular}

Description: $\mathrm{B}=$ Weight

Source: FAO / WHO / UNO, 1985 cited from the Booklet of Athlete Regulation of MOH RI.

Table 2: Energy Requirements For Various Sports Branch (cal / kg BB / 24)

\begin{tabular}{|c|c|c|c|c|}
\hline Gender & $\begin{array}{c}\text { Light } \\
\text { exercise }\end{array}$ & $\begin{array}{c}\text { Moderate } \\
\text { exercise }\end{array}$ & $\begin{array}{c}\text { Heavy } \\
\text { sports }\end{array}$ & $\begin{array}{c}\text { Extremely } \\
\text { heavy sports }\end{array}$ \\
\hline Man & 42 & 46 & 54 & 62 \\
\hline Woman & 36 & 40 & 47 & 55 \\
\hline
\end{tabular}

Source: Modification based on data from FHO / WHO 1974 from sports book of DepPenNas 2002

\section{A. Calculation of Physical Activity}

How to calculate energy requirement for physical activity is by using factor of multiples BMR. The heavier the activity the higher the factor, as listed in the table below.

Table 4: Energy requirements for physical activity

\begin{tabular}{|l|c|c|}
\hline \multirow{2}{*}{ Type of activity } & \multicolumn{2}{|c|}{$\begin{array}{c}\text { Estimated energy reduction } \\
\text { (multiples of BMR) }\end{array}$} \\
\cline { 2 - 3 } & Man & Woman \\
\hline 1. Sleep & 1,0 & 1,0 \\
\hline 2. Activity in work & & \\
\hline$-\quad$ Light, easy & 1,7 & 1,7 \\
\hline - $\quad$ Medium & 2,7 & 2,2 \\
\hline - Weight & 3,8 & 2,8 \\
\hline 3. Sports activities & 6,0 & 6,0 \\
\hline 4. Relaxing moments & 1,4 & 1,4 \\
\hline
\end{tabular}

Source: modification based on data from FHO / WHO / 1974 from sports nutrition book DEPPENNAS

\section{B. Type of activity}

To facilitate in analyzing the types of activities required then by Kunkun (1996: 35) categorized the activities to be:

1) Sleep $(0.9-10 \mathrm{kcal})$

2) Very light $(1,4-1,5 \mathrm{kcal})$

Reading, writing, watching tv or cinema, listening to radio, sewing, playing cards, typing, various types of office work and other work done with little sitting or hand gestures.

\section{Research Methodology}

The datas are colleted by using "descriptive method". With this method the main issue of the state of nutritional status of 


\section{International Journal of Science and Research (IJSR) \\ ISSN (Online): 2319-7064 \\ Index Copernicus Value (2016): 79.57 | Impact Factor (2015): 6.391}

Petanque athletes of North Sumatra can be expressed in a systematic and directed. Because the subject matter has been more focused and focused, that is just want to know one aspect of the state of nutrition status Petanque athletes of North Sumatra, then this method is more precise and known as Narrow Survey is a narrow and simple. The characteristic feature of this method is that more people try / sample use the better the results, but with smaller trial people within certain limits, the results are quite significant. Therefore this method is appropriate for the above problems.

\section{Research Instruments}

Instrument of research conducted is to use way of assessment of nutritional status of athletes based on anthropometric measurement of Body Mass Index (BMI) or Body Mass Index (BMI). This method is used to determine the nutritional status of adults aged 18 years or older. The way of assessment is to use the following formulation:

$$
\text { Body mass index }=\frac{\text { Weight }}{\text { Height }(\mathrm{M}) 2}(\text { Djoko, 73:2006) }
$$

Furthermore, the calculation result of Body Mass Index is consulted with the following table:

\begin{tabular}{|c|c|c|}
\hline Nutritional status & Man & Woman \\
\hline Thin & $<20,1$ & $<18,7$ \\
\hline Normal & $20,1-25,00$ & $18,7-23,8$ \\
\hline Obese & $>30$ & $>28,6$ \\
\hline
\end{tabular}

\section{Research Result and Discussion}

From the data obtained through the results of research, then processed by using the assessment of nutritional status based on anthropometry measurements Body Mass Index (BMI), then obtained the following results

Table 6. Measurement Result of Body Mass Index (BMI) Petanque Athletes of North Sumatera

From table 6 above it can be explained that to find an assessment of nutritional status of Petanque athletes of North Sumatra, done by calculating Body Mass Index (BMI). Where to know Weight in kilograms, Height in meters, and this measurement can only be used for adults (age 18 years and over).

Based on the result of the research, it is found that the overall nutritional status of Petanque athletes in the normal category is 21.92. This value has been converted to a nutritional status table where the values of $20.1-25.0$ are in the normal category. While individually obtained the result of as much as 93 percent (14 people) Petanque athletes of North Sumatra have normal nutritional status. Only 7 percent (1 person) are in the category of obesity.

By looking at the table above, then every North Petanque athlete can be known how much the number of caloric values by adjusting the athletic numbers that they do. The following will describe the daily caloric needs of each Petanque athlete of North Sumatra.

Table: List of Petanque Athletes Sumut and Result of Measurement of Body Mass Index (BMI) Petanque Athletes of North Sumatra

\begin{tabular}{|c|l|c|c|c|c|c|c|c|c|}
\hline No & \multicolumn{1}{|c|}{ Nama } & $B B$ & $T B$ & Umur & $T B$ & $I M T$ & Status & rata-rata TB & rata-rata IMT \\
\hline 1 & M.Bayu Pebrian & 54 & 1,64 & 18 tahun & 2,69 & 20,08 & Normal & 2,69 & 20,08 \\
\hline 2 & Satria & 80 & 1,86 & 19 tahun & 3,46 & 23,12 & Normal & 3,46 & 23,12 \\
\hline 3 & Yoel Ganda Srg & 55 & 1,59 & 19 tahun & 2,53 & 21,76 & Normal & 2,53 & 21,76 \\
\hline 4 & Erdi Anugrah & 56 & 1,61 & 19 tahun & 2,59 & 21,6 & Normal & 2,59 & 21,6 \\
\hline 5 & Pumareka Tarigan & 57 & 1,66 & 23 tahun & 2,76 & 20,69 & Normal & 2,76 & 20,69 \\
\hline 6 & Nosanta & 108 & 1,88 & 20 tahun & 3,53 & 30,56 & obese & 3,53 & 30,56 \\
\hline 7 & Andriadi Putra S & 95 & 1,85 & 21 tahun & 3,42 & 27,76 & Normal & 3,42 & 27,76 \\
\hline 8 & Johannes Damanik & 52 & 1,65 & 19 tahun & 2,72 & 19,1 & Normal & 2,72 & 19,1 \\
\hline 9 & Yuyun Danati M & 56 & 1,64 & 21 tahun & 2,69 & 20,82 & Normal & 2,69 & 20,82 \\
\hline 10 & Delvina Theresia & 54 & 1,58 & 20 tahun & 2,5 & 21,63 & Normal & 2,5 & 21,63 \\
\hline 11 & Audio Lumban Gaol & 58 & 1,65 & 21 tahun & 2,72 & 21,3 & Normal & 2,72 & 21,3 \\
\hline 12 & Loed Afandi & 59 & 1,69 & 20 tahun & 2,86 & 20,66 & Normal & 2,86 & 20,66 \\
\hline 13 & Suanetral & 52 & 1,58 & 19 tahun & 2,5 & 20,83 & Normal & 2,5 & 20,83 \\
\hline 14 & Rebekka S & 46 & 1,58 & 21 tahun & 2,5 & 18,43 & Normal & 2,5 & 18,43 \\
\hline 15 & M.Ridwan & 55 & 1,64 & 23 tahun & 2,69 & 20,45 & Normal & 2,69 & 20,45 \\
\hline & & & & Jumlah & $\mathbf{4 2 , 1 6}$ & $\mathbf{3 2 8 , 7 9}$ & Normal & $\mathbf{2 , 8 1 0 6 6 6 6 6 7}$ & $\mathbf{2 1 , 9 1 9 3 3 3 3}$ \\
\hline
\end{tabular}

Thus every Petanque athlete of North Sumatera absolutely need sufficient nutrient intake, considering the need of calorie which must be issued very big that is $4600 \mathrm{~s} / \mathrm{d} 6000$ kcal. If the caloric needs obtained from the intake of small nutrients, then the calorie needs to do the exercise of athletic branch numbers is not sufficient. Over time the athlete will experience malnutrition.

Although the results of this study indicate nutritional status in normal circumstances, the manager of Petanque North Sumatra should also pay more attention to the daily athletes menu. Because based on the questionnaire filled by the sample, the food menu they consume is less varied. This means that the food menu is not variegated, so it can reduce their will to eat the food.

\section{Conclusion}

Based on the results of research conducted can be concluded that the nutritional status of Petanque athletes of North Sumatra is in the normal category.

\section{Volume 6 Issue 12, December 2017}




\section{International Journal of Science and Research (IJSR) \\ ISSN (Online): 2319-7064}

Index Copernicus Value (2016): 79.57 | Impact Factor (2015): 6.391

\section{Suggestion}

1) We recommend that the Petanque athletes food menu of North Sumatra is maintained and if necessary more improved, considering the number of calories needed to run a large enough exercise activity.

2) Better Petanque Northut athlete rest pattern more attention, to anticipate athletes who are late to sleep at night.

3) Required family support (parents) to help supply extra food athletes.

4) Food menu given to Petanque Sumut athletes should be monitored by nutritionists.

\section{References}

[1] Achmad Djaeni Sedia Oetama. Nutrition Sciences for Professions and Students. Jakarta: Dian Rakyat, 1991.

[2] Asmuni. Human and Sports. Bandung:

[3] Depdiknas, Learning Physical Education in Elementary School, Jakarta, 2005.

[4] Muhibin Shah. Psychology Learning.Jakarta: Rajawali Pers, 2007.

[5] Santrock W. Jhon, Educational Psychology, Jakarta: Kencana, 2007.

[6] Sudjana, Statistical Method, Bandung: Tarsito, 2002.

Volume 6 Issue 12, December 2017

www.ijsr.net 